\title{
Comparison of recommendations in national/ regional Guidelines for prevention and control of MRSA in thirteen European countries
}

S. Kalenic ${ }^{1}$, B. Cookson ${ }^{2}$, R. Gallagher ${ }^{3}$, W. Popp ${ }^{4}$, A. Asensio-Vegas ${ }^{5}$, O. Assadian ${ }^{6}$, A. Blok ${ }^{7}$, S. Brussafero ${ }^{8}$,

A. Eastaway ${ }^{9}$, P. Elstrom ${ }^{10}$, M. Girod Schreinerova ${ }^{11}$, P. Hartemann ${ }^{12}$, R. B.G. Iversen ${ }^{10}$, B. Jans ${ }^{13}$,

A. Jul-Jorgensen ${ }^{14}$, W. Koller ${ }^{6}$, A. Kramer ${ }^{15}$, D. Laugesen ${ }^{16}$, M. Licker $^{17}$, K. Mannerquist ${ }^{18}$, B. Nussbaum ${ }^{19}$,

P. Parneix ${ }^{20}$, T. de Ruiter ${ }^{21}$, E. Tvenstrup Jensen ${ }^{22}$, L. Ummels ${ }^{23}$, K.-D. Zastrow ${ }^{24}$

${ }^{1}$ University of Zagreb, Medical School, University Hospital Centre Zagreb, Dpt for Clinical and Molecular Microbiology, Zagreb, Croatia

${ }^{2}$ Laboratory of Health Care Associated Infection (LHCAI) (London, United Kingdom) and WHO Reference and Research Centre, London, UK

${ }^{3}$ Royal College of Nursing, London, UK

${ }^{4}$ Universitätsklinikum Essen, Essen, Germany

${ }^{5}$ Preventive Medicine Department, University Hospital Puerta de Hierro-Majadahonda, Madrid, Spain

${ }^{6}$ Department for Hygiene and Medical Microbiology, Division of Hospital Hygiene, Medical University of Vienna, Vienna, Austria

${ }^{7}$ Region Nordjylland, Infektionshygiejnen, Aalborg, Denmark

${ }^{8}$ Department of Clinical and Experimental Pathology, University of Udine, Hospital Hygiene

and Risk Management Unit, Udine University Hospital, Udine, Italy

${ }^{9}$ Health Protection Scotland, Glasgow, UK

${ }^{10}$ Norwegian Institute of Public Health, Oslo, Norway

${ }^{11}$ Ministry of Health, Department of Epidemiology, Prague, Czeck Republic

${ }^{12}$ Service d'Hygiène Hospitalière, Centre Hospitalier Universitaire de Nancy, France

${ }^{13}$ Scientific Institute of Public Health, Brussels, Belgium

${ }^{14}$ Hillerød Hospital, Hillerød, Denmark

${ }^{15}$ Institut für Hygiene und Umweltmedizin der Universität Greifswald, Greifswald, Germany

${ }^{16}$ Sydvestjysk Sygehus, Esbjerg, Denmark

${ }^{17}$ University of Medicine and Pharmacy, Temisoara, Rumania

${ }^{18}$ Swedish Institute for Infectious Disease Control (SMI), Solna, Sweden

${ }^{19}$ Stiftung Orthopädische Univ.-Klinik, Heidelberg, Germany

${ }^{20}$ Southwestern Healthcare-Associated Infection Control Centre Bordeaux University Hospital, Bordeaux, France

${ }^{21}$ Groene Hart Ziekenhuis, Gouda, The Netherlands

${ }^{22}$ National Centre on Antimicrobials and Infection Control, Statens Serum Institut, Copenhagen, Denmark

${ }^{23}$ University Medical Centre St Radboud, Nijmegen, The Netherlands

${ }^{24}$ Institut für Hygiene und Umweltmedizin, Berlin,Germany

doi: 10.3396/ijic.V6i2.016.10

\section{Corresponding author}

Smilja Kalenic, University of Zagreb, School of Medicine, University Hospital Centre Zagreb, Dpt for Clinical and Molecular Microbiology, 10000 Zagreb, Kispaticeva 12, Croatia, Phone: +385 12367318 ,

Mobile: +38598301 443, E-mail: skalenic@mef.hr, smilja.kalenic@zg.htnet.hr 


\begin{abstract}
A comparison of methicillin-resistant Staphylococcus aureus (MRSA) prevention and control recommendations, as stated in national/regional guidelines of 13 European countries was performed based on a structured questionnaire filled by representatives of professional societies or institutions. The aim of this study was to be a source of guidelines, references and views which can inform discussions at national/regional/local levels. Countries were devided in two groups based on proportion of MRSA in blood cultures positive with Staphylococcus aureus retrieved from EARSS 2008: low proportion (4 countries) and higher proportion (9 countries). Guidelines from all respective countries have several common general recommendations: MRSApositive patients have to have the same care as those that are not carrying MRSA, hand hygiene measures including the use of alcohol hand rubs are identified as important in the prevention of MRSA spread, environmental cleaning and/or disinfection has to be performed routinely, and personal protective equipment has to be used whilst working with MRSA positive patients. Surveillance and screening is also a part of all guidelines. Major differences among low and higher MRSA proportion countries, identified as successful practices, were: have guidelines and update it regularly, have guidelines not only for hospitals, but also for nursing homes and home practice, isolate MRSA positive patients in single room, perform MRSA screening based on risk categories in hospitals and nursing homes, and perform decolonisation of MRSA carriers.
\end{abstract}

\title{
Key Words
}

MRSA, prevention recommendations, guidelines

\section{Introduction}

In November 2008 representatives of 12 European scientific and professional societies involved in Healthcare Associated Infection ( $\mathrm{HCAl}$ ) prevention and control met in Berlin to initiate a discussion on possible collaboration in the field of HCAI prevention and control at European level. Two more countries have since joined the group in June 2009. One of the particular topics of the discussion was prevention and control of MRSA in the Societies' respective countries, as members identified this as a current and major issue in infection prevention and control. National representatives presented an outline of their MRSA prevention and control measures and other data in a short presentation at the meeting. As the incidence and prevalence of MRSA is very different amongst European countries, the decision was made to compare different recommendations for prevention and control of MRSA as stated in national/regional guidelines, with the aim to be a source of guidelines, references and views which can inform discussions at national/regional/ local levels.

\section{Methods}

National guidelines were defined as those that were implemented throughout the country, while regional ones were defined as those implemented in a specific county. A tabular questionnaire based on topics presented during the meeting was sent to every country representative and they were asked to fill in additional data from their national/regional guidelines on MRSA prevention and control. New members from these 13 countries joined the group thereafter and added to the dataset and the writing of the paper. Thirteen of the 14 country representatives responded. One country was unable to provide details of national/ regional guidelines, and although local guidelines (i.e. those produced and used by a particular hospital in a country) were identified they were excluded on this occasion.

Data from thirteen countries have therefore been included, based on national/regional guidelines on prevention and control of MRSA. ${ }^{1-22}$ MRSA bloodstream infection incidence was retrieved from EARSS 2008. ${ }^{23}$ 


\section{Results}

\section{Basic Guideline and MRSA incidence data}

Basic guideline and MRSA incidence data are shown in Table I. Two countries (Austria and Czech Republic) have no national but regional guidelines. In Austria, most of the nine federal states have guidelines that are similar in very many parts. Czech Republic has only a national recommendation and local guidelines (in some hospitals), so data were used solely from the national recommendation.

Guidelines from all respective countries have several common general recommendations:

- MRSA-positive patients have to have the same care as those that are not carrying MRSA

- Hand hygiene measures including the use of alcohol hand rubs are identified as important in the prevention of MRSA spread

- Environmental cleaning and/or disinfection has to be performed routinely

- Personal Protective Equipment has to be used whilst working with MRSA positive patients

\section{MRSA in hospitals}

Table II summarises screening and isolation policies in hospitals. MRSA surveillance is mentioned in all national guidelines presented, with significant variation identified: for example, between recommendations for surveillance of MRSA in clinical specimens: from bacteraemia only (UK, Czech Republic) or isolates from any site (Croatia). The date of the first implementation of MRSA surveillance programmes varied widely e.g. UK 1986, Belgium 1994, Germany 2001, France nationally 2002 (but regionally since 1993) and Croatia 2009, and whether surveillance is mandatory (Belgium [since 2006, before the date on a voluntary basis] Germany, Norway, Sweden, The Netherlands, UK, France) or on a voluntary basis (Austria, Croatia, Czech Republic, Italy, Spain). In Denmark, surveillance was voluntary until November 2006, after which it became notifiable for all bacteraemia and other clinical isolates, at the time of their first detection. Since 2006 Austrian hospitals are obliged by a Federal act to participate in any nosocomial infection surveillance network based on scientificaly accepted standards - which

Table I: General country data relating to guidelines and proportion of MRSA/total S.aureus causing bloodstream infections

$\begin{array}{llllllllllllll}\text { Country NO* } & \text { SW“ NL } & \text { DEN } & \text { AU } & \text { CZ } & \text { GER\# } & \text { BE } & \text { FR } & \text { ESP } & \text { UK } & \text { IT } & \text { HR }\end{array}$

\begin{tabular}{llllllllllll}
\hline First issue & $1999-1970$ & 1980 & 1994 & 1999 & 2006 & 1999 & 1993 & 19992008199520052008 \\
& 2004 & & & 2006 & 2003 & & 2004 & 2003 & & & \\
& & & & & & & 2005 & 2005 & & &
\end{tabular}

\begin{tabular}{|c|c|c|c|c|c|c|c|c|c|c|c|}
\hline $\begin{array}{l}\text { Last } \\
\text { revision }\end{array}$ & 2008 & 2006 & 2008 & 2008 & $\begin{array}{l}2006 \\
2007\end{array}$ & 2008 & $\begin{array}{l}\text { Ongoing: } \\
\text { Hospitals } \\
\text { and } \mathrm{NHs}\end{array}$ & 2009 & & $2006-$ & - \\
\hline
\end{tabular}

$\begin{array}{llllllllllllll}\text { Proportion } & 0.6 & 0.7 & 0.7 & 2.3 & 8.2 & 14.2 & 19.5 & 20.6 & 24.5 & 26.6 & 30.7 & 33.5 & 35.4\end{array}$
of MRSA

(EARSS

2008)

$\mathrm{NO}=$ Norway, $\mathrm{SW}=$ Sweden, $\mathrm{NL}=$ The Netherlands, $\mathrm{DEN}=$ Denmark, $\mathrm{AU}=$ Austria, $\mathrm{CZ}=\mathrm{Czech}$

Republic, GER=Germany, BE=Belgium, FR=France, ESP=Spain, UK=United Kinngdom, IT=Italy, HR=Croatia

+ Yes; -No; empty NO DATA; *infection notifiable since 1995, colnozation since 2005; "notifiable since 2000; \#notifiable since 2005 
indirectly also implies surveillance of MRSA-cases. In France, surveillance of both specific infections and all primoisolates is mandatory from 2005, and indicators were publically reported for the first time in 2009 (data for 2005-2007).

Screening for carriers is also a part of all guidelines (Table II). Risk categories for patient screening in all guidelines are: patient with previous MRSA infection/ colonization, patients with previous hospitalization or admitted from nursing homes; some countries screen also patients admitted from abroad (Croatia) or outside Scandinavia (Denmark, Norway, The Netherlands); furthermore, patients before high risk procedures or admitted to intensive care units. Besides general risk factors, in Spain every hospital sets own risk factors. Austria, Denmark, Norway and The Netherlands have additional risk categories specific for patients: chronic skin conditions, indwelling medical devices. The Netherlands and Germany have another additional risk factor: patients living in pig farms. Dutch guidelines have very detailed risk categories (Category 1 to category 4) that is helpful in everyday patient care. France has targeted approach advised by hospital HCAI Committee. Positive patients are cared for as shown in table II.
All guidelines recommend isolation of MRSA positive patients.

\section{MRSA in nursing homes}

Belgium (2005), Germany (2005), France (2004, revised 2006), Norway (2002), The Netherlands and UK (1995) have separate guidelines for MRSA in nursing homes, while Austria, Croatia, Denmark, and Sweden have nursing homes included in general MRSA guidelines. Other countries have no specific recommendations for nursing homes. Out of these ten countries, only Norway and Sweden recommend tracking of cases, Denmark recommended surveillance in 2006 (at time of first clinical detection), Norway and Croatia also recommend MRSA surveillance. Austria, Belgium, Norway and Sweden recommend MRSA screening (Norway - same as for hospitals) based on risk categories, and Germany, Denmark and The Netherlands screen only in outbreak situations. In England screening of nursing home residents is mandatory and occurs prior to elective admissions to hospitals or at the time of non-elective admissions is recommended. The isolation policy for MRSA positive residents differs in different guidelines, and most guidelines recommend isolation of MRSA positive residents only in situation of some clinical conditions

Table II: Screening and isolation policies in hospitals

\begin{tabular}{|c|c|c|c|c|c|c|c|c|c|c|c|c|c|}
\hline Country & NO & SW & NL & DEN & $\mathrm{AU}$ & $\mathrm{CZ}$ & GER & $\mathrm{BE}$ & FR & ESP & UK & IT & HR \\
\hline Screening & $\begin{array}{l}\text { Risk } \\
\text { cathe- } \\
\text { gories }\end{array}$ & $\begin{array}{c}\text { Risk } \\
\text { cathe- } \\
\text { gories }\end{array}$ & $\begin{array}{c}\text { Four } \\
\text { risk } \\
\text { cathe- }\end{array}$ & $\begin{array}{c}\text { Defined } \\
\text { risk } \\
\text { groups }\end{array}$ & $\begin{array}{c}\text { Defined } \\
\text { risk } \\
\text { groups }\end{array}$ & $\begin{array}{l}\text { Risk } \\
\text { cathe- } \\
\text { gories }\end{array}$ & $\begin{array}{l}\text { Specific } \\
\text { patients }\end{array}$ & $\begin{array}{l}\text { Defined } \\
\text { risk } \\
\text { groups }\end{array}$ & $\begin{array}{l}\text { Targeted } \\
\text { approach }\end{array}$ & Voluntary & $\begin{array}{c}\text { Risk } \\
\text { groups* }\end{array}$ & $\begin{array}{l}\text { Risk } \\
\text { groups }\end{array}$ & $\begin{array}{l}\text { Defined } \\
\text { risk } \\
\text { groups }\end{array}$ \\
\hline $\begin{array}{l}\text { Isolation: } \\
\text { Single room }\end{array}$ & + & + & + & + & & & & & & & & & \\
\hline $\begin{array}{l}\text { Single room } \\
\text { or cohorting }\end{array}$ & & & & & + & + & + & + & + & + & + & + & + \\
\hline Gloves & + & + & + & + & + & + & + & + & + & + & + & + & + \\
\hline Gowns & + & + & + & + & + & + & + & + & + & + & + & + & + \\
\hline Masks & $+^{* *}$ & $+\#$ & $t^{* *}$ & + & + & $+\#$ & + & + & $+\# \#$ & $+^{* *}$ & $+\#$ & $+\#$ & + \\
\hline $\begin{array}{l}\text { Proportion } \\
\text { of MRSA } \\
\text { (EARSS } \\
2008 \text { ) }\end{array}$ & 0.6 & 0.7 & 0.7 & 2.3 & 8.2 & 14.2 & 19.5 & 20.6 & 24.5 & 26.6 & 30.7 & 33.5 & 35.4 \\
\hline
\end{tabular}

See Table One for country names

+ Yes; -No; empty NO DATA; *All elective surgical pts by $1 / 4 / 09,{ }^{* *}$ surgical masks, \# risk assessment 
(pneumonia, secreting wounds) or other risk factors, while in all other situation residents are allowed to have social contacts.

Hand hygiene is emphasised in all guidelines. Other details are presented in Table III.

\section{MRSA in general practice and home care}

Czech Republic, Italy and Spain do not include general practice or home care in their guidelines. Austria has only general recommendations for general practice and home care. Germany does not include any regulation concerning general practice and home care, but hand hygiene is emphasised. Since 2009, in Germany regional networks recommend improving communication, information sharing and cooperation between the healthcare sectors. Sweden recommends only basic precautions for general practice and home care, as well as France; all other countries emphasise hand hygiene while working with MRSA positive patients. Other details are presented in Table IV.

\section{Table III: MRSA in Nursing Home}

\begin{tabular}{|c|c|c|c|c|c|c|c|c|c|c|c|c|c|}
\hline Country & NO* & $\mathrm{SW}^{* *}$ & NL & DEN\# & $\mathrm{AU}$ & $\mathrm{CZ}$ & GER & $\mathrm{BE}$ & FR & ESP & UK & IT & $\mathrm{HR}^{*}$ \\
\hline $\begin{array}{l}\text { Guideline: } \\
\text { None }\end{array}$ & & & & & & None & & & & None & & None & \\
\hline Separate & + & & + & & & & + & + & + & & + & & \\
\hline $\begin{array}{l}\text { In general } \\
\text { guideline }\end{array}$ & & + & & + & + & & & & & & & & + \\
\hline Screening & + & + & $\begin{array}{c}+ \\
\text { (outbreak) }\end{array}$ & \begin{tabular}{|c|}
+ \\
(outbreak)
\end{tabular} & + & & \begin{tabular}{|c|}
+ \\
(outbreak)
\end{tabular} & + & - & & $\begin{array}{c}+ \\
\text { (prior } \\
\text { el.hosp } \\
\text { ad.) }\end{array}$ & & - \\
\hline $\begin{array}{l}\text { Isolation: } \\
\text { Yes/No }\end{array}$ & + & + & $+^{* * *}$ & $+\&$ & + & & $+* * *$ & $++^{* * *}$ & - & & NS & & $+* * *$ \\
\hline Single room & + & + & + & & + & & & & $\begin{array}{c}+ \text { if } \\
\text { possible }\end{array}$ & & & & + \\
\hline $\begin{array}{l}\text { Single room } \\
\text { or cohorting }\end{array}$ & & & & + & & & + & + & & & + & & \\
\hline Gloves & + & + & + & & + & & + & + & $+\#$ & & + & & + \\
\hline Gowns & + & + & + & - & + & & + & + & $+\#$ & & + & & + \\
\hline $\begin{array}{l}\text { Masks } \\
\text { Cleaning/ } \\
\text { disinfection }\end{array}$ & $\begin{array}{c}+ \\
\text { Daily }\end{array}$ & $\begin{array}{c}- \\
\text { Point } \\
\text { dis. }\end{array}$ & $\begin{array}{c}+ \\
\text { (surgical) } \\
\text { Daily }\end{array}$ & $\begin{array}{l}\text { Daily and } \\
\text { discharge }\end{array}$ & $\begin{array}{l}+ \\
+ \\
+\end{array}$ & & $\begin{array}{l}\text { Only } \\
\text { high } \\
\text { risk }\end{array}$ & $\begin{array}{l}+ \\
+\end{array}$ & $\begin{array}{c}+\# \\
\text { Not } \\
\text { Specific }\end{array}$ & & $\begin{array}{l}- \\
+ \\
+\end{array}$ & & $\begin{array}{l}+ \\
+\end{array}$ \\
\hline $\begin{array}{l}\text { Proportion } \\
\text { of MRSA } \\
\text { (EARSS } \\
2008)\end{array}$ & 0.6 & 0.7 & 0.7 & 2.3 & 8.2 & 14.2 & 19.5 & 20.6 & 24.5 & 26.6 & 30.7 & 33.5 & 35.4 \\
\hline
\end{tabular}

See Table One for country names

+ Yes; -No; empty NO DATA; * Surveillance recommanded, **Tracking of cases; \#Surveillance recommanded since 2006; ${ }^{* * *}$ if risk factor identified; \& if clinical infection can not be contained; \#\# for close contact; NS not stated 
Table IV: MRSA in General practice and Home care

\begin{tabular}{|c|c|c|c|c|c|c|c|c|c|c|c|c|c|}
\hline Country & NO & SW & NL & DEN & $\mathrm{AU}$ & CZ & GER & BE & FR & ESP & UK & IT & HR \\
\hline $\begin{array}{l}\text { Patient } \\
\text { visit }\end{array}$ & $\begin{array}{l}\text { Standard } \\
\text { prec- } \\
\text { autions }\end{array}$ & $\begin{array}{c}\text { Basic } \\
\text { prec- } \\
\text { autions }\end{array}$ & $\begin{array}{c}\text { Standard } \\
\text { prec- } \\
\text { autions }\end{array}$ & $\begin{array}{l}\text { At the } \\
\text { end of } \\
\text { the day }\end{array}$ & & & & $\begin{array}{c}\text { Guideliness } \\
\text { actually } \\
\text { developing }\end{array}$ & $\begin{array}{c}\text { National } \\
\text { guidelines } \\
(2004, \\
\text { revised } \\
2006)\end{array}$ & & \begin{tabular}{|c|} 
End of \\
day for \\
dressing \\
advised
\end{tabular} & & $\begin{array}{l}\text { Standard } \\
\text { prec- } \\
\text { autions }\end{array}$ \\
\hline $\begin{array}{l}\text { Home } \\
\text { care }\end{array}$ & $\begin{array}{l}\text { Standard } \\
\text { prec- } \\
\text { autions }\end{array}$ & \begin{tabular}{|l|} 
Track \\
cases
\end{tabular} & $\begin{array}{l}\text { Single } \\
\text { room }\end{array}$ & $\begin{array}{c}\text { Treatment } \\
\text { and care } \\
\text { in } \\
\text { patient } \\
\text { bedroom }\end{array}$ & & & & & $\begin{array}{c}\text { Standard } \\
\text { prec- } \\
\text { autions }\end{array}$ & & \begin{tabular}{|c|} 
End of \\
day if \\
possible, \\
use of \\
protective \\
clothing
\end{tabular} & & $\begin{array}{l}\text { Standard } \\
\text { prec- } \\
\text { autions }\end{array}$ \\
\hline $\begin{array}{l}\text { Proportion } \\
\text { of MRSA } \\
\text { (EARSS } \\
2008 \text { ) }\end{array}$ & 0.6 & 0.7 & 0.7 & 2.3 & 8.2 & 14.2 & 19.5 & 20.6 & 24.5 & 26.6 & 30.7 & 33.5 & 35.4 \\
\hline
\end{tabular}

See Table One for country names

+ Yes; -No; empty NO DATA

\section{MRSA carriers}

All Guidelines include the management of MRSA carriers and have an approach to the screening of staff members in outbreak situations. Sweden and The Netherlands advise screening if staff have been working abroad, and Norway does the same as for their patients. France advises screening staff only if staff carriage could be associated with an outbreak amongst patients.

If decolonisation is indicated, all countries have the same or a very similar decolonization regime which comprises the use of mupirocin intranasally three times per day for five days and total body washing in chlorhexidine solution. Germany recommends at least three days mupirocin regimen, or some other antiseptic in the nose and does not specify the antiseptic for body washing; Belgium recommends a povidone iodine or chlorhexidine body wash. Other details are shown in Table V.

MRSA in policy, insurance and legal implications All countries data are shown in Table VI.

\section{Discussion}

The comparison between 13 European countries' Guidelines for MRSA prevention was made using a questionnaire sent to national representatives. The advantage of this study design was that the participants did not need to translate the documents and knew how to interpret the statements accurately. A drawback was that we did not compare the guidelines in their totality, but adopted a pragmatic approach focusing on those aspects that our expert group thought were the most important. Another possible drawback was that it was not possible to judge compliance with the guidelines, or judge other factors that are thought to be important for effective implementation such as government and/ or hospital management initiatives. These might include financial incentives or fines and legislation on healthcare associated infection (or MRSA prevention and control) which might underpin guideline implementation, as well as differences in the delivery of health care, such as size and complexity of hospitals, isolation facilities (e.g. availability of single rooms), and staff-patient ratios and bed occupancy. In addition MRSA can vary even within a country and 
Table V: MRSA carrier decolonisation

\begin{tabular}{|c|c|c|c|c|c|c|c|c|c|c|c|c|c|}
\hline Country & NO & SW & NL & DEN & $\mathrm{AU}$ & CZ & GER & BE & FR & ESP & UK & IT & HR \\
\hline Staff & + & $\begin{array}{l}\text { Individual } \\
\text { approach }\end{array}$ & + & + & + & $\begin{array}{l}\text { Individual } \\
\text { approach }\end{array}$ & + & + & $\begin{array}{l}\text { If possibly } \\
\text { associated } \\
\text { with an } \\
\text { outbreak } \\
\text { among } \\
\text { patients }\end{array}$ & $\begin{array}{l}\text { Individual } \\
\text { approach }\end{array}$ & + & + & + \\
\hline Patients & + & $\begin{array}{l}\text { Individual } \\
\text { approach }\end{array}$ & + & + & + & \begin{tabular}{|c|} 
Before \\
risk \\
procedure
\end{tabular} & + & + & \begin{tabular}{|c|} 
+ for targeted \\
at risk \\
situations
\end{tabular} & + & + & $\begin{array}{c}\text { + in high } \\
\text { risk } \\
\text { wards }\end{array}$ & + \\
\hline $\mathrm{NH}$ residents & + & - & + & + & & & & + & - & & & & + \\
\hline $\begin{array}{l}\text { At home: } \\
\text { patients }\end{array}$ & $+^{*}$ & - & + & + & & - & & & - & & $+* *$ & & - \\
\hline $\begin{array}{l}\text { At home: } \\
\text { Family } \\
\text { members }\end{array}$ & $t^{*}$ & - & + & + & & - & & & - & & - & & - \\
\hline $\begin{array}{l}\text { Proportion of } \\
\text { MRSA } \\
\text { (EARSS } \\
2008 \text { ) }\end{array}$ & 0.6 & 0.7 & 0.7 & 2.3 & 8.2 & 14.2 & 19.5 & 20.6 & 24.5 & 26.6 & 30.7 & 33.5 & 35.4 \\
\hline
\end{tabular}

See Table One for country names

+ Yes; -No; empty NO DATA; *if clinically indicated or working/patient in home care/health care institution;

${ }^{* *}$ only if clinically indicated; $\mathrm{NH}=$ Nursing home

we could not consider the applicability of the stated guidelines to the local situation and how much these can vary.

Although most of the guidelines had recommendations relating to most of the selected topics, there were nevertheless some differences. If we compare two groups of countries, namely the ones with very low MRSA proportions (Norway, Sweden, The Netherlands and Denmark) with the other countries, we can see several important points: all four low proportion countries had written their initial Guidelines before the year 2000 whilst only $5 / 9$ with higher MRSA proportion had agreed them before that year. Furthermore, these four very low MRSA proportion countries also had recommendations for nursing homes, general practice and home care, whilst only six of the other nine countries had recommendations for nursing homes and three of these for general practice and home care.
Interestingly, all four low proportion countries have MRSA infections (colonisations) as notifiable, while only 4/9 higher proportion countries have the same. This is contextually very interesting, in that MRSA has clearly increased in some countries where there were guidelines in place (e.g. England, Germany). Other factors must be considered to explain the increases in MRSA that are now observed in these countries.

All guidelines recommend screening of patients based on risk categorisations, but when it came to reviewing the patient isolation, the four low incidence countries recommended single rooms, whilst all nine higher incidence countries recommended single room or cohorting of MRSA positive patients. This no doubt relates to their side room capacity often being exceeded. ${ }^{24}$ The much debated issue of wearing masks when there is contact with MRSA positive patients was reflected in some differences between approaches. In 
Table VI: MRSA in policy, insurance and legally

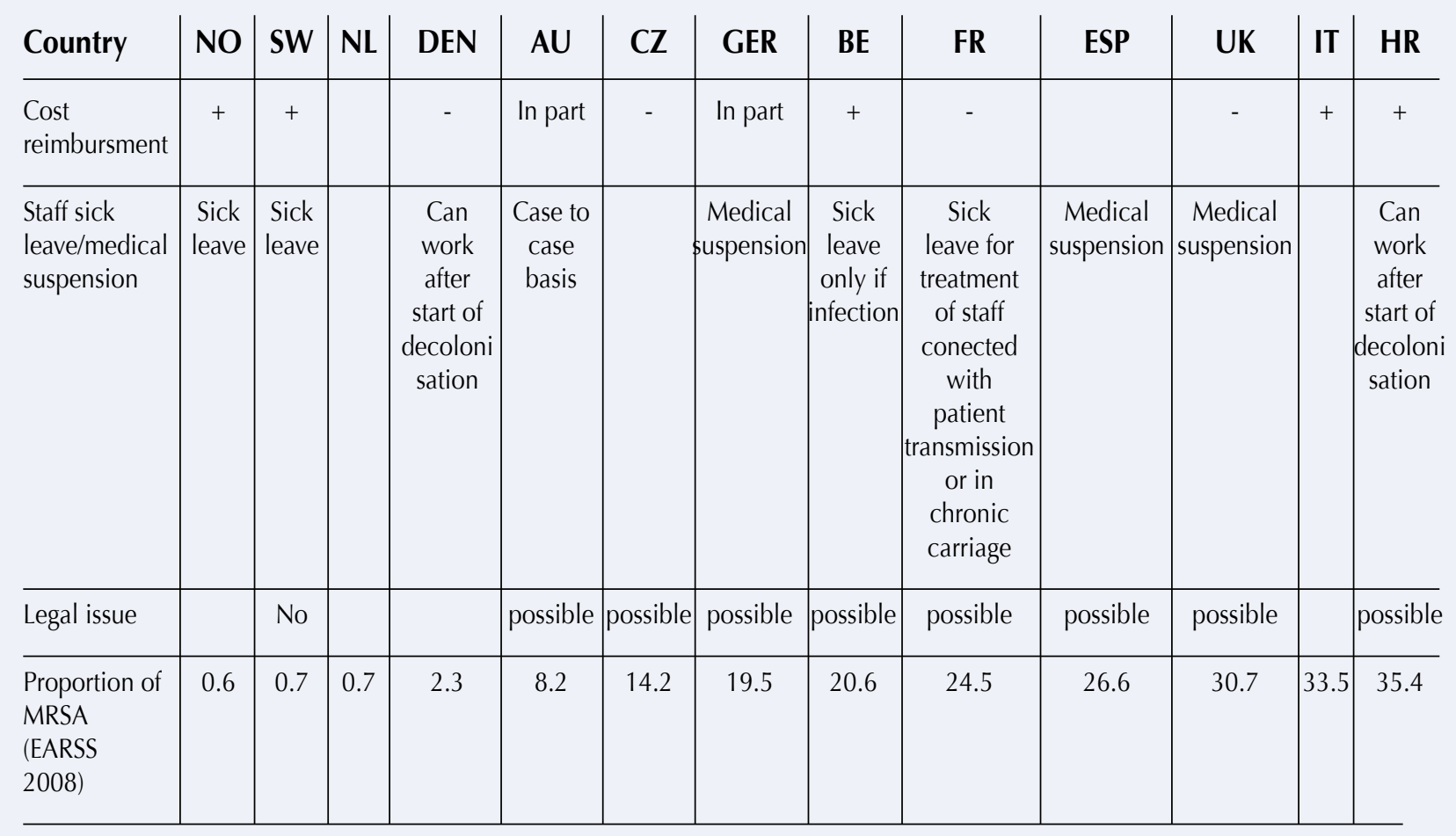

See Table I for country names

+ Yes; -No; empty NO DATA

the Czech republic, UK, Italy and Sweden masks were recommended only if there was risk of aerosols (e.g. aspiration of patient with pneumonia), whilst all the remaining countries recommended it for any contact.

For usage of gloves, there are also some differences between countries: while in Austria, Croatia, Czech Republic, Germany, The Netherlands and UK, gloves should be worn at entry to the isolation room, in Belgium, Denmark, France, Norway, Spain and Sweden gloves are used in close contact with patients, and Italian (Simpios) Guidelines do not specify this item.

There were also differences seen between recommendations for decolonisation of MRSA carriers. Whilst Norway, The Netherlands and Denmark recommend decolonisation of all carriers, Sweden recommends a risk assessment approach for staff and hospital patients. France recommends staff decolonisation only if possibly associated with an outbreak among patients, and for patients in targeted at risk situations. Other countries' recommendations are very different for either staff or hospitalized patients although we did not explore the evidence base they used to justify their approach. This would be an interesting area for future work.

Our survey seems to indicate that successful practices would be to include guidelines which are reviewed and updated regularly in line with changing knowledge about the epidemiology, MRSA types and factors that could influence spread of these organisms. Many such factors would need to be considered including skilled staff/patient ratios, intensity of patient care, lengths of hospital stay for the different specialties, numbers and types of inter-ward transfers, ability to close wards and still deliver effective hospital care. Antimicrobial usage has also been found to be associated with a higher MRSA occurrence. ${ }^{25}$ In addition, we did not explore the mechanisms in place locally or nationally to audit and review MRSA prevention and control practices. In England there has been the interesting approach of using mandatory target setting for reductions of MRSA 
bacteraemia, although there are less data on the total MRSA burden in the country.

Some countries, such as France, have added process surveillance performance indicators which, for example, assess alcohol hand rub product usage. National hand hygiene campaigns are implemented in some countries e.g. France, Belgium and England.

These recommendations should be not only for hospitals, but also for nursing homes, general practice and home care. This is increasingly important as healthcare delivery now involves the whole healthcare economy and patients are transferred between these components with very short length of hospital stay for many procedures and investigations.

To facilitate a coordinated approach, and recognize the movement of patients between primary care, secondary (acute) facilities, and tertiary (highly skilled specialist) centres, it may help to make MRSA infections notifiable. However, some countries have considered this and do not wish to add to the burden imposed by this reporting system and have used other approaches e.g. mandatory surveillance.

Our survey indicates that the practices of isolating MRSA positive patients in single room, perform MRSA screening based on risk categories in hospitals and nursing homes, and decolonisation of MRSA carriers may well be the most successful, and are commended as best practice. Our recommendations also take into account the findings of the ARPAC study which showed lower MRSA occurrence in European countries was associated in linear regression model with use of alcohol-based solutions for hand hygiene and placement of MRSA patients in single rooms. Hospitals with problems in implementing isolation policies had higher resistance levels. Clearly the levels of MRSA are so high in some countries that the capacity of their side rooms and other isolation facilities is exceeded ${ }^{24}$. Other interventions such as cohort nursing of patient need to be introduced. Their effectiveness should, however, be monitored together with further research into factors such as nursing establishments, the use of dedicated nurses and impact of skill on potential spread from such facilities as suggested previously.

\section{Reference:}

1. National guideline for prevention and control of methicillin resistant Staphylococcus aureus (MRSA) in health care institutions. Revised version, published Sep. 2008 (Norway) http://www.fhi.no/dav/d487882515.pdf

2. Att förebygga vårdrelaterade infektioner, Socialstyrelsen 2006, in English Preventing health care related infections, National Board of health and welfare 2006 Regulations on basic hygiene in Swedish health care service etc.,SOSFS 2007:19 National Board of health and welfare 2007, www.socialstyrelsen.se

3. Dutch Working Party on infection Prevention (WIP) Guidelnies: www.wip.nl

4. Danish guidelines are found at the following link: http://www. sst.dk/Udgivelser/2008/Prevention\%20of\%20MRSA\%20 spreading\%20-\%20Guidelines.aspx?lang=en

5. http://www.meduniwien.ac.at/krankenhaushygiene Division of Hospital Hygiene, Medical University of Vienna and Vienna General Hospital

6. http://www.wien.gv.at/ma15/arbeitskreis/richtlinien.htm Arbeitsgruppe Krankenhaushygiene Wien (2006). Hygieneplan MRSA für Krankenhäuser und Geriatriezentren.

7. www.bmgfj.gv.at/cms/site/attachments/8/9/5/CH0620/ CMS1192607322878/prohyg_leitlinie.pdf Recommendation of the Austrian Ministry of Health for organisation and strategy in hospital hygiene; Vienna, 2002, ISBN 3-85010-100-2

8. Recommendation for control of occurence of methicillinresistent Staphylococcus aureus (MRSA) and with other dangerous rezistence in health care facilities Zprávy CEM (SZÚ, Praha 2006, ročník 15, př́loha 1) Script:“Doporučený postup pro kontrolu výskytu kmenů Staphylococcus aureus rezistentních $k$ oxacilinu (MRSA) a $s$ jinou nebezpečnou antibiotickou rezistencí ve zdravotnických zařízeních."

9. Mitteilung der Kommission für Krankenhaushygiene und Infektionsprävention am RKI: Empfehlung zur Prävention und Kontrolle von Methicillin-resistenten Staphylococcusaureus-Stämmen (MRSA) in Krankenhäusern und anderen medizinischen Einrichtungen. Bundesgesundhbl Gesundheitsforsch Gesundheitsschutz 1999; 42: 954-958.

10. Mitteilung der KRINKO und des RKI: Kommentar zu den „Empfehlungen zur Prävention und Kontrolle von MRSAStämmen in Krankenhäusern und anderen medizinischen Einrichtungen“. Epidem Bull 2008; 42: 363-364. (topic mainly screening recommendations)

11. Empfehlung der Kommission für Krankenhaushygiene und Infektionsprävention am RKI: Infektionsprävention in Heimen. Bundesgesundhbl Gesundheitsforsch Gesundheitsschutz 2005; 48: 1061-1080. (about nursing homes)

12. Health Council \& BICS. Guidelines for the control and prevention of methicillin-resistant Staphylococcus aureus transmission in Belgian hospitals (available in English, French and Dutch from Last revision: June $2005 \mathrm{https} / / /$ portal.health. fgov.be/portal/page?_pageid=56,512429\&_dad=portal \&_ schema=PORTAL)

13. Belgian Infection Control Society (BICS). Mesures préventives de la transmission du Staphylococcus aureus résistant à la méthicilline(MRSA)danslesmaisondereposetdesoins.Available from http://www.belgianinfectioncontrolsociety.be/index.php? mact=Uploads,cntnt01, getfile,0\&cntnt01 showtemplate=false $\&$ cntnt01upload_id $=57 \&$ cntnt01 returnid $=67 \& h \mathrm{~h}=\mathrm{fr} \_F R$ www. belgianinfectioncontrolsociety.be Recommendations pour le contrôle et la prévention de la transmission de Staphylococcus aureus résistant a la Méthicilline dans les hôpitaux Belges BICS/ CSS ; Mesure préventives de la transmission du Staphylococcus aureus résistant a la Méethicilline (MRSA) dans les maisons de repos et de soin BICS/ISP 
14. Ministere de l'Emploi at de la Solidarite. Secretariat d'Etat a la Sante et a l'action sociale. Comite Technique des Infections Nosocomiales. Maitrise de la diffusion des bacteries multiresistantes aux antibiotiques- 1999 (URL: http://www. sante.gouv.fr/htm/pointsur/nosoco/bacteries/maitbact.html)

15. Société Française d'Hygiène Hospitalière. Prevention de la transmission croisee: precautions complementaires contact, avril 2009 (URL: http://www.sfhh.net/telechargement/ recommandations_preventiontransmissioncroiseeSFHH.pdf)

16. Ministère de la Santé et de la solidarité. Infections liées aux soins réalisés en dehors des établissements de santé : guide de prévention. Janvier 2006 (URL: http://nosobase.chu-lyon.fr/ recommandations/Medecinedeville/guideministere2006.pdf)

17. Rodríguez-Baño, C Bischofberger, F Alvarez-Lerma, A Asensio, T Delgado, D García-Arcal, L García-Ortega, MJ Hernández, J Molina-Cabrillana, C Pérez-Canosa, M Pujol y Grupos de Estudio de Infección Hospitalaria (GEIH) y de Infección en el Paciente Crítico (GEIPC) de la Sociedad Española de Enfermedades Infecciosas y Microbiología Clínica (SEIMC) y Sociedad Española de Medicina Preventiva, Salud Pública e Higiene (SEMPSPH). Vigilancia y control de Staphylococcus aureus resistente a meticilina en hospitales españoles. Documento de consenso GEIH-SEIMC y SEMPSPH. Enferm Infecc Microbiol Clín 2008; 26: 285-298.

18. Ayliffe GAJ, BrumfittW, Casewell MWC, et al . Guidelines for the control of epidemic methicillin-resistant Staphylococcus aureus. Report of a combined working party of the Hospital Infection Society and the British Society of Antimicrobial Chemotherapy. J Hosp Infect 1986; 7: 193-201.
19. Ayliffe GAJ, Brumfitt W, Casewell MWC, et al . Guidelines for the control of epidemic methicillin-resistant Staphylococcus aureus in elderly care and nursing homes. Report of a combined working party of the Hospital Infection Society and the British Society of Antimicrobial Chemotherapy. I Hosp Infect: 1995; 31: 1-12.

20. Coia JE, Duckworth GJ, Edwards DI, et al. Guidelines for the control and prevention of meticillin-resistant Staphylococcus aureus (MRSA) in healthcare facilities. J Hosp Infect 2006; 63 (suppl 1): S1-S44.

21. Raccomandazioni per il controllo della diffusione dei cocchi gram-positivi multiresistenti: Staphylococcus aureus meticillina-resistente (MRSA) ed Enterococcus spp vancomicina-resistente (VRE) http://www.simpios.org/ufiles/ File/posPapers/MRSA.pdf

22. Guidelines for Prevention, Control and Treatment of infections caused by methicillin-resistant Staphylococcus aureus (MRSA). Lijecn Vjesn 130 (Suppl 1): 1-32.

23. The European Antimicrobial Resistance Surveillance System www.earss.rivm.nl

24. Cooper BS, Medley GF, Stone SP, et al. Methicillin-resistant Staphylococcus aureus in hospitals and the community: Stealth dynamics and control catastrophes. Proc Nat Acad Sciences 2004: 6: 10223-10228.

25. MacKenzie FM, Bruce J, Struelens MJ, Goossens H, Mollison J, Gould IM, and ARPAC Steering Group members. Antimicrobial drug use and infection control practices associated with methicillin-resistant Staphylococcus aureus in European Hospitals. Clin Microbiol Infect 2007; 13: 269-276. 